\title{
Social Policy in Germany: The Dual Model of the Social State
}

\author{
Stefanos Koffas \\ Department of Social Work, Frederick University, Cyprus
}

\begin{abstract}
In the Federal Republic of Germany the exercise of social policy is based on the corporatist-conservative model and its particular form of dual organization, with the participation of state and non-state agencies being institutionally determined. A brief historical overview of the creation of the social state in Germany is initially presented, along with the effect of the historical facts, the political and socioeconomic characteristics of the German system so that the composition and the operational philosophy of the dual form of the corporatist model can become clear. Next, the analysis centres on the structures, and the way in which the principles and organizational characteristics of the dual model of sociopolitical intervention are setup based on the provisions of its institutional framework of operation. The ulterior objective is to comprehend the main elements that define the administrative and executive synergy between the state and specific agencies of the social sector that contribute to the operation of the dual organizational model of the social state in Germany.
\end{abstract}

Keywords Germany Social Policy, Corporatist-conservative Model, Dual Form of Organization

\section{Introduction}

The German social state has its roots in the reforms of the Bismarck administration, undertaken primarily for political and secondly for economic reasons; the measures that were introduced concerned mainly employment in order to placate the demands of the numerous working classes (Lampert \& Althammer, 2001). Furthermore, one cannot overlook the fact that since the $19^{\text {th }}$ century, structures of the church ministry have a strong tradition of contribution to assistance towards fellow humans through different forms of offer. This fact, along with historical and social reasons of co-existence, and even more so the respect for the values of collectivism and solidarity established in the perception of the people of Germany a particular intervention system in the social sector. More specifically, the state is not, either on its own or by precedence, responsible to alleviate social needs, economic inequalities or uncovered urgent needs. The adopted practice applies the principles of solidarity and collective offer by all the participants, according to the abilities of each (Frerich \& Frey, 1996).

In order to implement the practice of different participants, each available resource, whether material (structures) or intangible (human resources), is utilized; this became elemental and has through time been the topic of discussion on the modus operandi and the reform efforts concerning the social policy of the Federal Republic of Germany. Hence, today the form of the social policy model takes into consideration, not only the Christian principles of solidarity and collectivism, but also the principle of personal responsibility within the context of social pluralism (Koffas, 2009, p. 118). Additionally the significant social, economic and demographic changes such as population fluctuations, the increase of life expectancy, frequent changes in the employment relationship, pose imperatively the need for synergy among the market economy, collective responsibility, but also individual contribution/participation of each person in a specified manner (Frerich \& Frey, 1996).

As a result, the German state by adhering to social pluralism and the social market economy instituted, also by law, certain agencies as formal partners in the exercise of social policy by creating the dual social policy model of the social state (Falterbaum, 2009, p.112). It is a very distinct model whose effectiveness is beyond doubt; its operation is a topic of study which could inspire other countries in regard to the synergy of the agencies involved for the better utilization of resources. The excellent working relationship of the agencies involved and the coordination of the overall effort by the state is what makes this model remarkable.

\section{The Social State in Germany}

The conditions of the socioeconomic and cultural environments of each country in combination with the particular characteristics of the culture and the idiosyncrasy ISSN: 2332-6840 (Online) 2332-6832 (Print) Copyright (C) 2016 by authors, all rights reserved. Authors agree that this article remains permanently open access under the terms of the Creative Commons Attribution License 4.0 International License 
of society are of material importance in the exercise of sociopolitical intervention. The different organizational, management, control and evaluation systems and the way the institutional framework is implemented are compositional factors and should be understood as elements of dynamic, combined interplay at all levels of connection, i.e. at the micro, middle as well as the macro levels. These are the factors that jointly shape social policy models through time and affect the manner of their implementation. Hence, depending on the changes in the circumstances, of any given time, at a national but also international level, social policy focuses on its redistributive function for those in need and financially dependent workers, or aims towards regulations that will ameliorate financial poverty in general, or even its importance is understood as a policy of providing equal opportunities to disadvantaged and socially weak vulnerable groups which require greater social attention (Sanmann, 1975, p.189)

In Germany it has been established and there is more mention of the social state, the social market economy and sociopolitical intervention because the development of state, social measures and programmes constituted from the start elements of the fundamental organizational and political debate about the constitution and the open relationship between economic and social order (Hartwich, 1978, in: Schäfers \& Zapf, 1998, p. 622). The existence and provision of a social state according to article 20, paragraph I of the Constitution of the Federal Republic of Germany belong to the primary incontestable principles of the Constitution and cannot be repealed even by a majority of two thirds (Zacher, 1977, p.154). According to Afheldt, the explanation of this legal wording means that the social state is a state which supports state social policy and within which "everyone finds employment, is able to afford an apartment to live in with his family and is provided with health care" (Afheldt, 1994, p. 12).

In the case of Germany, according to Schönig, the intervention of the social state, besides any other factors, is also determined by its field of action (situation analysis), what follows in order to cover confirmed needs in society (purpose analysis) and what means, to achieve this purpose, are confirmed to exist (means analysis) (Schönig, 2001, p.64). The tools used for the implementation of sociopolitical intervention are not solely limited to state means, but also involve the synergy of resources available in the non-state, mainly private, sector as well as the voluntary sector. The participation of all parties in the implementation of the German social state takes place under a dual organizational form. The state regulates through legislation the form and type of intervention, giving the right to selected non-governmental partners to jointly deal with certain issues, such as care, security and handling adverse circumstances in people's lives. There is, therefore, an institutionally organized form of apportioning intervention types among state services and a certain number of authorized partners; the first deal mainly with the redistributive economic function for society as a whole, while the second mostly address issues on covering personal needs at an individual level. Hence, state services deal with material issues and primarily safeguard the smooth operation of the social security system, while the authorized non-governmental partners are oriented towards handling needs of a psychosocial nature and risks that emanate from structural/functional weaknesses of the capitalistic modern society (Böhnisch, Arnild \& Schröer, 1999, p.239).

\section{Factors in the Creation of the Social State in Germany}

\section{The Historical Influence of Political Liberalism and Socialism}

The German state's official intervention, through institutionalized measures, in social life can be traced back to the handling of the social problems of the $19^{\text {th }}$ century. The idea of the creation of the early social state "brought along a change in the previous understanding of the state's role, since up until that time the social, economic and cultural development of society was the responsibility and decision of the individuals themselves (ideology of liberalism). New needs meant that the state had to become active in the social sector too, in order to redress social injustices among population groups" (Informationen zur politischen Bildung, 1992, p.1). In Germany, legislative state intervention in the social sector may be explained as the outcome of a series of various historical developments and social changes with the most important being the organization of mass production at an industrial level, but also the effects of political liberalism and socialism. All these developments altered the traditional ways of living and activity for the majority of the population and became the starting point of a society oriented towards capitalism (Schaefers \& Zapf, 1998, p.300ff).

From the end of the $18^{\text {th }}$ century political liberalism had a favourable effect on the industrialization of production and brought important changes to many sectors of social activity. More specifically, it provided the impetus to personal rights which up until that time were quite limited and under the control of the aristocratic elite, and also contributed to the creation of egalitarianism among citizens. People, as free citizens of the state now, acquired civil rights, the capacity to determine their own lives and pursue their own financial, political and cultural interests. However, within the context of the new and more intense liberal competitive financial activity among people, the interrelationships between productive forces changed resulting in the emergence of winners and losers, rich and poor. Significant differences between population groups appeared in regard to social status, prosperity and quality of life which reflected the new interrelationships of the socioeconomic process (Informationen zur politischen Bildung, 1992, p.3ff). The changes brought about by the early capitalism of 
liberalization resulted in the emergence of a massive number of unskilled labourers, known as the proletariat, who led a life of suffering and destitution in poverty and misery; this situation became known as social issues. Addressing those pressing needs of financial and social nature, and logistics, prompted, among others, the development of the first state care interventions, which were also the outcome of dealing with the organized social movements and the dynamic form of the demands of destitute population groups (Lampert \& Althammer, 2001, p.14; Holtmann, 2000, p.630; Schmidt, 1981).

The political ideology of socialism tried to contribute to the solution of social problems and address the poverty and destitution of the population within the context of the Marxist view, by pointing out the power of the labour asset when they rally and claim their rights from the manufacturers-their exploiters. As a prerequisite for reinstating the balance of social life, socialism advocated the actual implementation of the principles of political liberalism and the ideas of the French Revolution in regard to the principles of equality, solidarity and freedom of people. Equal rights for citizens could be achieved only by state intervention. In such a case the state, as supreme authority, should exercise control over the production means to prevent exploitation and at the same time develop a central plan for the redistribution of goods and services, thus ensuring social justice (Kreft \& Mielenz, 1996, p.539ff).

The creation process of capitalism and the industrialization of production, along with the institutionalization of social rights, intellectual movements, humanitarianism, social movements and social demands laid the groundwork for the development of social policy in Germany. The earlier form of Christian charity towards fellow human beings was succeeded by state intervention with specific measures and legislative regulations which led, through time, to the creation of the modern social state.

\section{The Effect of Pluralism of the Modern Age}

The logic behind the design of the structure of the modern social state in the Federal Republic of Germany can be explained as the result of political compromise between competing systems of different strength. The social security system with the particularity of its dual form shows that responsible for this special structure between the political system and the social state model is not only a simple causality of hierarchy. A rather institutionalized connection exists between the two, the operation of which depends on regulatory compliance. The exact explanation of this connection is found in the synergy/pluralism which ought to exist between political, social and economic factors.

In the case of the political factor, driving forces are the principles of pluralism within the operation of the liberal model which determine the direction of all social activity sectors. It is this orientation of the political system that lends gravity to the promotion of synergy in important sectors of political and social life, and as a product of a long-established practice rather follows the logic of the "middle-of-the-road policy" (Schmidt, 1990). This means that in the case of the German social state it was not the social market economy model that was applied - in accordance to the influence of northern European states with social democratic systems -, but neither was the liberal-pluralistic model really established - in the form of non-controlled liberal capitalism. What happened was that through the representation of the interests of those involved in the political processes and the organized groups at the political level, as well as through compromises among social partners, the structure of the social security system was created in the federal German state. The participants in this structure are the driving force behind every effort of political decision making and play an important role when it comes to changes in legislation, but also to reformation efforts in the social sector (Siegel, 2002, p.291f).

A second important influence factor on the social state is the use of high-technology in manufacturing, which is related to the dominant power of the market economy and its effect on state social intervention. Within the context of the applied traditional middle-of-the-road sociopolitical model, with it's centrally run state intervention, economic policy is designed and implemented in such a way so as to reinforce the social state and at the same time, to the extent possible, not to be unfavourable to the freedom of economic competition and social order (Siegel, 2000, p.294). The objective of the said policy is to involve as many parties as possible in a productive process, in the sense of corporate social responsibility and the redistribution of part of the outcome to benefit development. For quite some time the synergy between the social state and economic development operates as a standard for the production model that promotes quality through competition and despite the difficulties arising every now and then due to the complexity of the interactions between political, economic and social sectors and institutions. This synergy continues to try and maintain a systemic balance in the often conflicting interests and power relationships among the participants. "The outcome of this complex integration between social and market forces, was the successful establishment of the capitalism of the social state, bearing a central influence on its operation, which in the case of Germany became known as the German model of social capitalism" (Van Kersbergen, 1995; Franz \& Immerfall, 1998; Joachem \& Siegel, 2000, in: Siegel, 2002, p.294).

In the meantime, changes in the work field, the now globalized competition in manufacturing and economic instability, brought difficulties to the middle-of-the-road model too, concerning mostly issues of allocation and undertaking of costs by the participating social partners. As a consequence, neoliberal criticism reemerged, which tabled the operation of the social state as a topic of political debate, mainly in connection with the implementation of economic management principles, such as effectiveness and 
performance, through the perspective of a necessary reorganization of, primarily, state intervention ${ }^{1}$. The operation of the, until recently, incontestable synergy of the economic and social sectors ended up being calculated more and more by the criterion of its effect on the cost-benefit relationship. Hence, state intervention according to the corporatist model, with its so far stabilizing effect on the operation of the sociopolitical system had to adjust to the rationalistic dictates and needs of the market economy (Koffas, 2009, p.115).

\section{The Special Nature of the Dual Social Security System}

The creation and development of the social state in Germany, under the influence of historical and social factors, was realized under the scope of a great many participants; the starting point being the effect of family and neighbourhood informal networks, soon after the contribution of religious institutions, by corporatist systems of vocational associations on matters of social security to its current form of the state redistributive operation. A cluster of heterogeneous foundations and organizations with multifarious objectives linked their demands to the development and operation of the social state. Crucial to its current structure is the regulatory interdependence and interplay between governmental and non-governmental partner agencies, as well as the form of their participation.

Therefore, governmental services within the structure of the social security system are geared towards securing the necessary resources to cover needs resulting from risks related to work and the income-earning ability of individuals, as well as general material difficulties that occur in a capitalistically organized market economy and the distortions that this causes. On the other hand, non-governmental organizations and foundations active in the social sector perceive their contribution to be more in the field of providing non-material services; such are psychosocial support, counseling and encouragement in problems arising due to changes in the circumstances of one's personal life, structural changes in the operation of society, intense situations and psychological factors that destabilize people who, for various reasons, can no longer cope (Böhnisch, Arnild \& Schröer, 1999, p.239f).

This common course and close cooperation between governmental agencies and an ever growing number of providers from the private and volunteer sectors led, in Germany, to the co-creation and exercise of a unique social policy system, which comprises two elements/agents, hence its description as a dual system (Sachse \& Tennstend, 1986). The type of the work provided and the conditions that

1 The augmentation of costs, in conjunction with techno-economic and socio-cultural changes, but also different governance systems put forward imperatively the issues of the size and effectiveness of the policies applied as described by most social policy scholars (Butterwegge, 2001; Ritter, 1989; Kaufmann, 1997; Vobruda, 1989; Lampert, 1997; Koch, 1995) that became known as the social state crisis. determine its fulfillment are specified and regulated by the institutional legal framework, in order to avoid overlaps or vagueness in regard to responsibilities. In accordance to this distinctive feature the organization and exercise of the dual system is divided not only among state and local government services, but includes the so called free agencies which provide services in the social sector. The latter includes private agencies of a social nature, such as associations, foundations, citizen organizations active on issues of social rights, limited liability companies, which are active in the fields of health, care, education, rehabilitation, for the youth, the elderly and, in general, anyone in need, excluding however the provision of benefits. The organizational structure of the dual system is precisely determined by specific legislative provisions and administrative frameworks which concern the form of activity of the free agencies in accordance to the federal system of Germany (Klatezki \& von Wadel-Parlowin: in Schaefers \& Zapf, 1998, p.570).

A significant difference between state services and free agencies of the social sector is the institutional framework regarding the allocation of their area of responsibility, which is based on the following characteristics:

- "The separation of the systems of social security, and social care and welfare

- The existence of boundaries in the production and supply of personal services and material goods

- The issue of managing the smooth operation of the multitude of social structures" (Schmid, 1996, p.48).

Germany's "dual form of the social state" (Leibfried \& Wagschal, 2000) constitutes a particular differentiation of the social intervention system because "it is based on two subsystems with a different internal logic regarding their organization, and where each one processes and is responsible for a separate part of service delivery. On the one hand, there is an objective division between social security and care/welfare, the sociopolitical handling of the policy that concerns workers and the policy that concerns the poor. On the other hand there is a separate institutional ranking of participants: between the central state at the federal level and the self-governing foundations under the influence of the local government of the federal states, but also of the unions" (Schmid, 1996, p.48). The fulfillment of this dual system in the structure of the social state, that is between state services and the free providers of social sector services is predefined and is included in the administrative framework of operation of the Federal Republic of Germany. It was indeed integrated in the description of the administrative structure, following the logic of compensating for additional areas of risk concerning specific population groups.

According to Goll (1991), an important reason for the development of the dual system was also the inadequacy of the free market to deliver personal services of a social nature to cover the existing demand, due to, among others, cuts both in social expenditure and the funding support of non-governmental agencies. A second reason was the very 
satisfactory experience acquired through the long-term cooperation between state and non-governmental, but also private agencies, especially those of Christian organizations; but also their higher efficiency and performance regarding service-users and fiscal results, compared to those services being provided solely by state agencies (Goll, 1991, p.46f, 50f). The above mentioned "advantages are owed to the dynamics of the pluralistic perspective, by the flexibility and innovation non-governmental agencies exhibit in their activities, the willingness to utilize the ever increasing supply of volunteers and their coordination, the familiarity and increased social sensitivity towards service-users, in contrast to and in comparison to the bureaucratic rigidity of state services" (Karolus, 1995, p.65). Those were the most important reasons, which with the passing of time as well, contributed to the establishment of the dual model of cooperation between the state and the free providers.

Another characteristic of the dual form is the strong administrative centralization of the free providers to a limited specified number, which have the legal right to contribute to the sector of sociopolitical intervention and which, in an auxiliary capacity to the state, are known in Germany as the main agencies of social welfare ${ }^{2}$. These are six, in number, large organizations which come from social movements and unions, and three from religious agencies that traditionally represent the main denominations of religious believers. The first category includes the Workers Welfare Association (AWO), the German Parity Association for Social Welfare (DPWV) and the German Red Cross (DRK). The church agencies include the German Ministry of the Catholic Church (DCV), the Ministry of the Protestant Church (DW) and the Central Welfare Service of the Jewish Synagogue (ZWSt) (Klatetzki \& von Wedel-Parlow, in: Schaefers \& Zapf, 1998, p.570).

According to the charter and provisions of each organization, the social welfare agencies focus their work on the delivery of specific personal services in the social sector, which are affected though by the contribution of the state, the market and the informal care network. Their strong independence from the state and the flexibility they exhibit during their work stems from the fact that their duties include primarily care services available to anyone who needs them. "Thus, they make sure to include services and programmes for covering needs at local government level, but also at federal state level, and consequently easily obtain the necessary authorizations for the services they offer and receive considerable funding at a federal and federal state level. At the same time, they follow, to a great extent, the operation of the free market economy and find themselves in competition with the private providers of the for-profit or

2 According to their charter, the main agencies of social welfare are associations of local agencies geared towards the social sector, providing services of a social nature; they adhere to specific values stemming from tradition and human collectivism, such as the opportunity of people to enjoy social life without exclusions, the decisions and self-determination of actions, the equitable and without hindrance access and representation of vulnerable or deprived social groups in efforts to assist them and demand their rights (Rauschenbach, Sachsse \& Olk, 1995, p.98). voluntary sectors that offer similar services. As such, despite being partially funded by the state, it is the authorized agencies of social welfare themselves that bear the risk for the efficiency of the work they have undertaken and the services they ought to deliver. Furthermore, they are obligated to continuously count on the renewal of the funding, their continued preference by the state, bearing in mind cost-benefit and result criteria, but also satisfaction criteria of their service-users" (Heimerl, 1995, p.44).

Therefore, as Hilpert (2001) points out, the relationship between social welfare agencies and state intervention cannot be considered a hand in hand relationship of providers, which are responsible for the same duties in regard to delivery of assistance, but neither antagonistic in regard to which people prefer when seeking assistance (Hilpert, in: Gabriel, 2001, p.73). The role of the free social welfare agencies mostly pivots around their function as representatives by promoting the interests and needs of people and the provisions of the state, aiming for the widest possible coverage. Their readiness to provide assistance in specific cases of people in need, reinforces their role and their interventions as representatives, especially when there is inefficiency by state services to provide material assistance or in the case of legal restrictions or even in cases of inability or unwillingness to serve due to bureaucracy. Due to exactly their function as intermediaries, the free social welfare agencies are the primary agencies people contact when seeking assistance; they enjoy greater trust as they are more conciliatory and efficient compared to the inflexible mechanism of the social state. The well-known case of German bureaucracy to proceed as prescribed, without the necessary flexibility of state services, underlines the clear preference for the free agencies by those seeking assistance. Due to this fact the relationship between the two parties in the dual system of the social state is described as being less and less of mutual assistance, but a rather practical one of completing each other (Hilpert, in: Gabriel, 2001, p.73; Heimerl,1995, p.45).

"This statutorily defined and delegated active involvement in the dual system of the social state, i.e. of state services and free social welfare agencies is achievable because there is both a close cooperation and at the same time certain autonomy in actions. Each of the participants has something specific and unique to offer, that the other partner would not be able to accomplish alone" (Hilpert, in: Gabriel, 2001, p.73). Yet the areas of cooperation of the participants do not remain the same over time; it is a rather complex balance of cooperation, during which changes take place in line with the challenges that appear at any given time. Lately though, this particular cooperative has lost many of its privileges, as the joint responsibility of free agencies and the state sector to provide care to those in need has altered the element of exclusiveness in the structure of the partnership. More specifically, the state sector proceeded to review in part the exclusive cooperation with the free agencies by reducing their funding/grant budget for the services they provide, by 
proceeding to accept private agencies too as equal partners, and by using ever more performance/outcome and cost criteria in its selections and transactions. In this manner, the state not only accomplished the development of new services agencies in the social sector, but also reinforced the competition among the interested parties, as receiving funding by the state budget became harder.

\section{Conclusions}

Despite those changes, state agencies and the traditional providers of social welfare services continue doing their work with mutual respect and to interact in this cooperation. "As such, the operational legislation of the social state is renewed according to the conditions of any given time and provides all participants with the essential legal framework for their operation and by guaranteeing the undisrupted continuation of their work. Furthermore, it assumes the responsibility for the overall planning for the delivery of social welfare services; it ensures that in areas where multiple providers are active in the same sector, resources will not be wasted due to unlawful competition, but neither will needs remain uncovered. Providers of social welfare services, on their part, undertake specific duties which they are obligated to fulfill and bear that responsibility by ensuring that they have the necessary resources, the appropriate staff and managerial structure (Hilpert, in: Gabriel, 2001, p.73f). Additionally, the free agencies are extremely active in the field of voluntary work and promote the willingness of people to offer their selfless participation in social and humanistic activities - elements that are unknown to the state and for-profit sectors. Therefore, as long as the free social welfare agencies maintain their capacity to deliver quality services that cover the needs of part of the population and coordinate the work of volunteers, they will continue to enjoy their privileged relationship with the state.

\section{REFERENCES}

Afheldt Horst, Wohlstadt fuer niemand? Die Marktwirtschaft entlässt ihre Kinder, München, 1994

Böhnisch Lothar, Arnild Helmut, Schröer Wolfgang, Sozialpolitik. Eine sozialwissenschaftliche Einführung, München, JuventaVerlag, 1999

Butterwegge Christoph, Wohlfahrtsstaat im Wandel, Opladen, Leske \& BudrichVerlag, 2001

Falterbaum Johannes., Rechtliche Grundlagen Sozialer Arbeit: eine praxisorientierte Einführung, 3. Auflage, Kohlhammer Verlag, 2009

Frerich Johannes., / Frey Martin, Handbuch der Geschichte der Sozialpolitik in Deutschland, 2. Auflage, Muenchen, Oldenbourg Verlag, 1996
Gabriel Karl, Sozialwissenschaftliche Abhandlung der Goerres Gesellschaft. Herausforderungen kirchlicher Wohlfahrtsverbände. Perspektive im Spannungsfeld von Wertbindung, Ökonomie und Politik, Band 25, Berlin, Duncker \& Humblot Verlag, 2001

Goll Eberhard, Die freie Wohlfahrtspflege als eigener Wirtschaftssektor. Theorie und Empirie ihrer Verbände und Einrichtungen, Baden-Baden, 1991

Hartwich Hans-Hermann, Sozialstaatspostulat und gesellschaftlicher Status quo, Opladen, 1978

Heimerl Peter, Wohlfahrtsverbände im Dritten Sektor. Entwicklung und Struktur der Arbeiterwohlfahrt Baden, Konstanz, Hartung-Gorre Verlag, 1995

Holtmann Everhard, Politiklexikon, München, Oldenburg Verlag, 2000

Immerfall Stefan and Franz Peter, Standort Deutschland: Stärken und Schwächen im weltweiten Strukturwandel, Opladen, Leske\&Budrich, 1998

Bundeszentrale für politische Bildung, Informationen zur politischen Bildung, Nr225, Bonn, 1992

Koffas Stefanos, Sozialpolitik in Deutschland und Griechenland. Eine Vergleichsuntersuchung $\mathrm{zu}$ ausgewählten Bereichen im Rahmen der EU-Sozialordnung, Eichstätt, Diritto Verlag, 2009

Kaufmann Franz-Xaver, Herausforderungen des Sozialstaates, Frankfurt, Suhrkamp Verlag, 1997

Karolus Greogor, Corporate Culture und Corporate Identity in Non-Profit Organisation, Frankfurt, 1995

Koch Claus, Die Gier des Marktes. Die Ohnmacht des Staates im Kampf der Weltwirtschaft, München/Wien, Carl Hanser Verlag, 1995

Kreft Dieter/ Mielenz Ingrid, Wörterbuch Soziale Arbeit, 4.Auflage, Weinheim, Basel, Beltz Verlag, 1996

Lampert Heinz, Krise und Reform des Sozialstaates, Frankfurt, Peter Lang Verlag, 1997

Lampert Heinz/Althammer Joerg, Lehrbuch der Sozialpolitik, 6. Auflage, Berlin, Heidelberg, Springer Verlag, 2001

Leibfried Stephan, Wagschal Uwe, Der deutsche Sozialstaat. Bilanzen-Reformen-Perspektiven, Frankfurt, Campus Verlag, 2000

Ritter A. Gerhard, Der Sozialstaat. Entstehung und Entwicklung im internationalen Vergleich, München, Oldenbourg Verlag, 1989

Sachse Christoph, Tennstend Florian, Soziale Sicherheit und Disziplinierung. Beiträge $\mathrm{zu}$ einer historischen Theorie der Sozialpolitik, Frankfurt, 1988

Sanmann Horst, Sozialpolitik, in: Ehrlicher W., Kompendium der Volkswirtschaftslehre, Band 2, 4. Auflage, Göttingen, 1975

Schaefers Berhhard and Zapf Wolfgang, Handwörterbuch zur Gesellschaft Deutschlands, Opladen, Leske \& Budrich Verlag, 1998

Schmidt Hans Ludwig, Theorien der Sozialpädagogik. Kritische Bestandsaufnahme vorliegender Entwürfe und Konturen einer Handlung theoretischen Neuansatzes, Rheinstetten, Schindele Verlag, 1981 
Schmid Josef, Wohlfahrtsverbände in modernen Wohlfahrtstaaten. Soziale Dienste in historisch-vergleichender Perspektive, Opladen, Leske \& Budrich Verlag, 1996

Schmidt Manfred G., Die Politik des mittleren Weges. Besonderheiten der Staatstätigkeit in der Bundesrepublik Deutschland, in: Aus Politik und Zeitgeschichte, Nr.9-10, 1990,

Schoenig Werner, Rationale Sozialpolitik, Berlin, Duncker \& Humblot Verlag, 2001

Siegel Nico, Baustelle Sozialpolitik. Konsolidierung und Rückbau im internationalen Vergleich, Frankfurt, New York, Campus
Verlag, 2002

Van Kersbergen Kees, Social Capitalism. A Study of Christian Democracy and the Welfare State, Routledge, London, 1995

Vobruda Georg, Die Entwicklung des Verhältnisses von Ökonomie und Sozialpolitik. Normen, Interessen und Theorien als Entwicklungsfaktoren, in: Vobruda G., Der wirtschaftliche Wert der Sozialpolitik, Berlin, 1989

Zacher Hans, Handwörterbuch der Wirtschaftswissenschaft, 7. Band, New York, Zurich, 1977 